\title{
PROSES SINTESIS DAN KARAKTERISASI FTIR HIDROKSIAPATIT DARI GIPSUM ALAM KULON PROGO
}

\author{
Joko Sedyono $^{\text {a }}$ dan Alva Edy Tontowi ${ }^{\mathrm{b}}$ \\ a. Teknik Mesin, Sekolah Pasca Sarjana UGM dan Teknik Mesin UMS \\ ๖. Teknik Mesin dan Industri UGM \\ e-mail:mas.joko@ymail.com
}

\begin{abstract}
ABSTRAK
Hidroksiapatit (HAp) $\left[\mathrm{Ca}_{10}\left(\mathrm{PO}_{4}\right)_{6}(\mathrm{OH})_{2}\right]$ telah dipergunakan secara luas dalam bidang kedokteran dan kedokteran gigi sebagai bahan substitusi tulang/gigi, hal ini karena komposisi dan strukturnya sama sebagaimana kandungan tulang/gigi. Tetapi HAp yang ada di Indonesia masih import. Tujuan dari penelitian ini adalah membuat bahan biokeramik hidroksiapatit dari gipsum alam Kulon Progo (KPNG) kemudian mengkarakterisasi dengan pengujian FTIR.

Sintesa HAp dilakukan dengan teknik Hydrohermal Microwave dengan mereaksikan antara KPNG $\left(\mathrm{CaSO}_{4} \cdot 2 \mathrm{H}_{2} \mathrm{O}\right)$ dengan diamonium hidrogen fosfat $\left[\left(\mathrm{NH}_{4}\right)_{2} \mathrm{HPO}_{4}\right]$. Kemudian hasil reaksinya dianalisa dengan pengujian FTIR dan dibandingkan dengan HAp 200 Jepang sebagai pembanding.

Dari hasil analisa didapat pola-pola FTIR hidroksiapatit hasil reaksi menyerupai HAp 200 Jepang dan HAp SRM 2910.
\end{abstract}

Kata Kunci: gipsum alam Kulon Progo, hidroksiapatit, FTIR

\section{PENDAHULUAN}

Kerusakan jaringan tubuh oleh berbagai kelainan, maupun penyakit, yang dapat menyebabkan kecacatan struktur yang akan menimbulkan gangguan fungsi tubuh, memerlukan restorasi untuk mengembalikan fungsi organ tubuh dengan sempurna. Penambahan atau penggantian jaringan merupakan salah satu rangkaian upaya memperbaiki kecacatan struktur tubuh.

Hidroksiapatit $\left[\mathrm{Ca}_{10}\left(\mathrm{PO}_{4}\right)_{6}(\mathrm{OH})_{2}\right]$ telah dipergunakan secara luas dalam bidang kedokteran dan kedokteran gigi sebagai bahan substitusi tulang, hal ini karena kandungan mayoritas tulang/gigi adalah hidroksiapatit (HAp). Dunia kedokteran Indonesia telah mengaplikasikan HAp, tetapi HAp yang ada di Indonesia masih import, padahal sangat berpotensi memproduksi sendiri HAp mengingat Indonesia adalah penghasil gipsum alam yang cukup potensial (misalnya di Kulon Progo Jogjakarta) untuk dikembangkan sebagai bahan baku pembuatan hidroksiapatit.

Tujuan penelitian ini adalah untuk mensintesa hidroksiapatit (Kulon Progo Hydroxyapatite/KPHAp) dari serbuk gipsum alam Kulon Progo $\left(\mathrm{CaSO}_{4} \cdot 2 \mathrm{H}_{2} \mathrm{O}\right)$ yang direaksikan dengan diamonium hidrogen fosfat $\left[\left(\mathrm{NH}_{4}\right)_{2}\right.$ $\mathrm{HPO}_{4}$ ] dengan metode hidrotermal menggunakan microwave kemudian dilakukan karakterisasi dengan pengujian FTIR (Fourier TransformInfra Red spectroscopy).

\section{TINJAUAN PUSTAKA}

Furuta dkk. (1998) mensintesa hidroksiapatit dari reaksi antara gipsum mold waste 5 x 10 x 20 mm dengan $40 \mathrm{ml}$ 0,5 M larutan diamonium hidrogen fosfat dengan cara hydrothermal treatment (conventional-hydrothermal) pada 
suhu $50-100^{\circ} \mathrm{C}$ dan dipelajari sifat-sifatnya. Di sini dia mengembangkan novel proses untuk mempersiapkan HAp monolith langsung dari gipsum waste dengan kristalisasi in situ dengan menggunakan reaksi kimia berikut:

$$
\begin{aligned}
& 10 \mathrm{CaSO}_{4} \cdot 2 \mathrm{H}_{2} \mathrm{O}+6\left(\mathrm{NH}_{4}\right)_{2} \mathrm{HPO}_{4} \rightarrow \\
& \mathrm{Ca}_{10}\left(\mathrm{PO}_{4}\right)_{6}(\mathrm{OH})_{2}+6\left(\mathrm{NH}_{4}\right)_{2} \mathrm{SO}_{4}+4 \mathrm{H}_{2} \mathrm{SO}_{4}+ \\
& 18 \mathrm{H}_{2} \mathrm{O}
\end{aligned}
$$

Diperoleh konversi gipsum ke HAp (100\%) pada suhu $50^{\circ} \mathrm{C}$ dalam waktu 15 hari dan $100^{\circ} \mathrm{C}$ dalam 2 hari.

Katsuki dkk. (1999) mensintesa HAp dengan microwave. Sintesa HAp diperoleh dari reaksi antara serbuk gipsum ( 0,5 gr) dan $40 \mathrm{ml}$ 0,5 M larutan diamonium hidrogen fosfat pada suhu $100^{\circ} \mathrm{C}$ selama $0,5-120$ menit dalam Teflon menggunakan sebuah microwave digestion system. Kemudian hasilnya dicuci dengan air murni, lalu dikeringkan pada suhu di bawah $50^{\circ} \mathrm{C}$. Untuk mengetahui pengaruh microwave, juga dilakukan reaksi yang sama dengan cara conventional-hydrothermal. Dengan cara microwave diperoleh konversi gipsum ke HAp (100\%) dalam waktu 5 menit, sedangkan dengan conventional-hydrothermal membutuhkan waktu 8 hari. Jadi lebih cepat menggunakan system microwave daripada conventional-hydrothermal.

Nasution (2006) mereaksikan serbuk kalsit [kalsium karbonat $\left(\mathrm{CaCO}_{3}\right)$ ] Gunung Kidul dengan larutan 0,5 $\mathrm{M}$ trisodium fosfat $\left(\mathrm{Na}_{3} \mathrm{PO}_{4} \cdot 12 \mathrm{H}_{2} \mathrm{O}\right)$ Wako Chemical Co., Japan untuk membuat hidroksiapatit(HAp). Prosesnya dengan perlakuan hidrotermal microwave pada suhu $100^{\circ} \mathrm{C}$. Setelah itu HAp hasil reaksi dikalsinasi pada suhu $800^{\circ} \mathrm{C}$ lalu dilakukan serangkaian pengujian. Dihasilkan hidroksiapatit yang pola FTIR-nya cukup mendekati hidroksipatit komersial HAp 200 Wako Jepang, tetapi masih mengandung kalsit.

\section{METODOLOGI PENELITIAN Rancangan Penelitian}

Penelitian ini akan dijalankan secara eksperimental laboratoris.

\section{Bahan Penelitian}

Bahan yang digunakan dalam penelitian ini adalah serbuk gipsum alam Kulon Progo (Kulon Progo Natural Gypsum/KPNG) [CaSO ${ }_{4}$. $2 \mathrm{H}_{2} \mathrm{O}$ ], butiran diammonium hydrogen phosphate (DHP), dan aquades. Kemudian sebagai pembanding digunakan gipsum murni, HAp 200 Jepang dan HAp SRM 2910 (Standard Reference Material dari National Institute of Standards and Technology, USA).

\section{Alat Penelitian}

Penelitian ini menggunakan beberapa alat yaitu: blender, timbangan mekanik, gelas beker, gelas ukur, gelas labu, batang pengaduk, microwave, kertas saring, kertas $\mathrm{pH}$, alat sieving, timbangan digital, dan mesin uji FTIR.

\section{Jalannya Penelitian}

\section{Alur penelitian}

Alur penelitian diperlihatkan pada Gambar 1.

\section{Pembuatan serbuk KPNG}

Untuk membuat serbuk KPNG dilakukan tahapan sebagai berikut (Sedyono dkk., 2007):

a. Melakukan penggalian di daerah Kulon Progo, Jogjakarta

b. Membersihkan dan memisahkan batuan gipsum dari tanah dan kalsit

c. Membuatserbukdenganmenggunakanblender

d. Sieving halus.

\section{Karakterisasi dan analisa data serbuk KPNG}

Untuk mengetahui apakah yang diperoleh itu adalah gipsum maka dilakukan karakterisasi dengan menggunakan FTIR, lalu dibandingkan dengan gipsum murni $\left(\mathrm{CaSO}_{4} \cdot 2 \mathrm{H}_{2} \mathrm{O}\right)$. Hal ini dilakukan supaya tidak keliru dengan material lain yang mirip gipsum (misalnya kalsit).

\section{Pembuatan KPHAp}

Proses sintesa KPHAp dilakukan dengan cara sebagai berikut (Sedyono dkk., 2007):

a. Menimbang DHP dengan timbangan mekanik untuk membuat larutan dengan konsentrasi 0,5 M 
b. Menimbang serbuk gipsum Kulon Progo untuk dicampur dengan larutan tersebut, dengan perbandingan 5 gr serbuk dan 400 ml larutan DHP

c. Larutan tersebut lalu dimasukkan ke dalam microwave dan dipanaskan (proses hidrotermal) pada suhu $100^{\circ} \mathrm{C}$ selama 30 menit

d. Larutan lalu dicuci dengan menggunakan aquades sekaligus disaring dengan menggunakan kertas saring beberapa kali sampai pH netral,

e. Kemudian serbuk dikeringkan dengan microwave.

\section{Karakterisasi dan analisa data serbuk KPHAp}

Untuk mengetahui apakah yang dihasilkan itu hidroksiapatit dan sejauh mana pola FTIR yang didapat, maka dilakukan karakterisasi dengan menggunakan FTIR, lalu membandingkannya dengan HAp 200 (Jepang), dan HAp SRM 2910.

\section{HASIL DAN PEMBAHASAN \\ Hasil Karakterisasi FTIR}

Hasil karakterisasi FTIR ditampilkan pada Gambar 2 dan Gambar 3, masing-masing untuk gipsum dan hidroksiapatit.

\section{Pembahasan}

Gambar 2 menunjukkan pola-pola FTIR yang sama antara KPNG (a) dengan gipsum murni (pembanding) (b) produk komersial yang ada di pasaran yang memiliki tingkat pro analisis (PA). Pola FTIR menunjukkan peak-peak dengan intensitas yang sangat kuat pada peak $11,777^{\circ}, 29,258^{\circ}$, dan $23,521^{\circ}$.

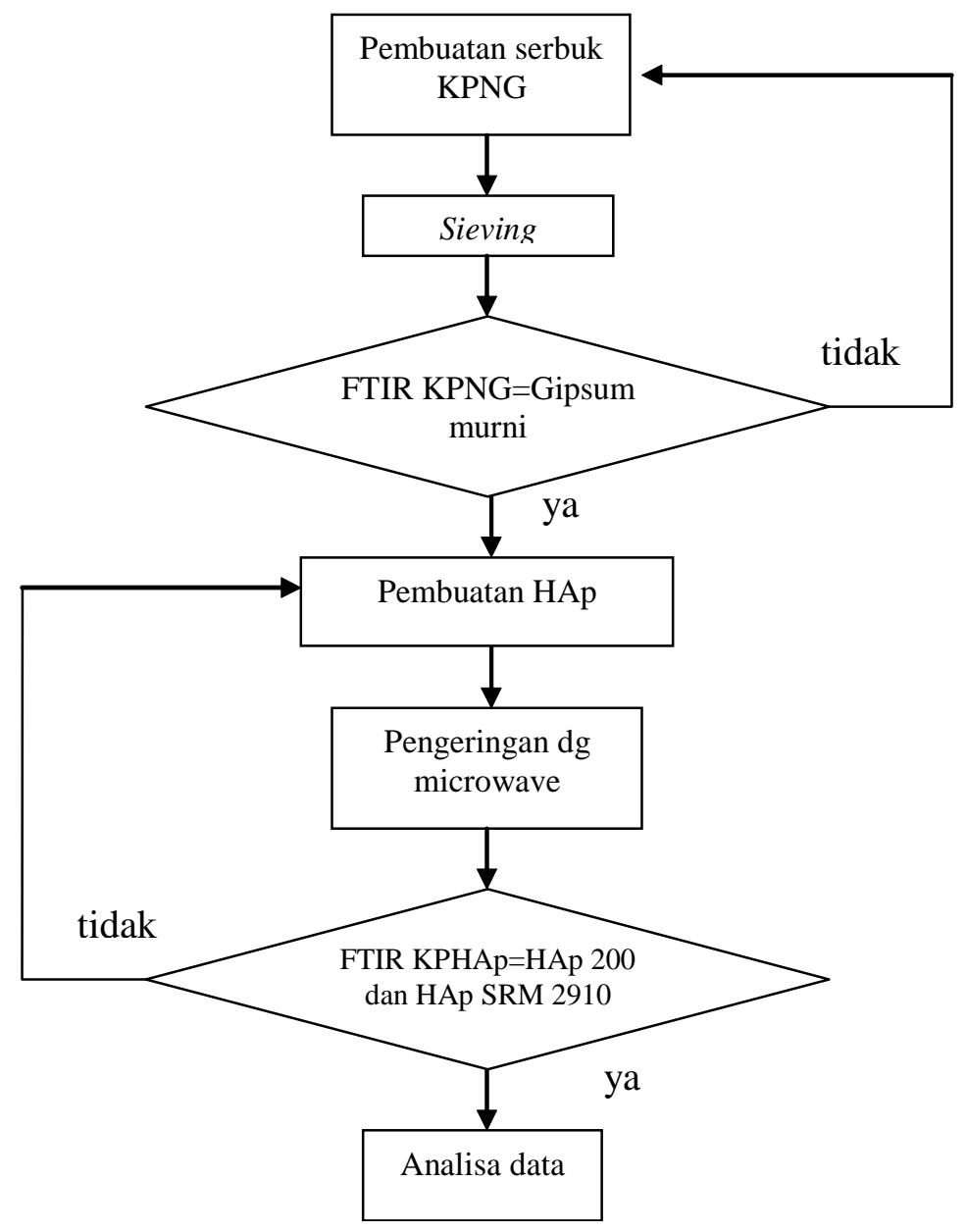

Gambar 1. Alur penelitian 


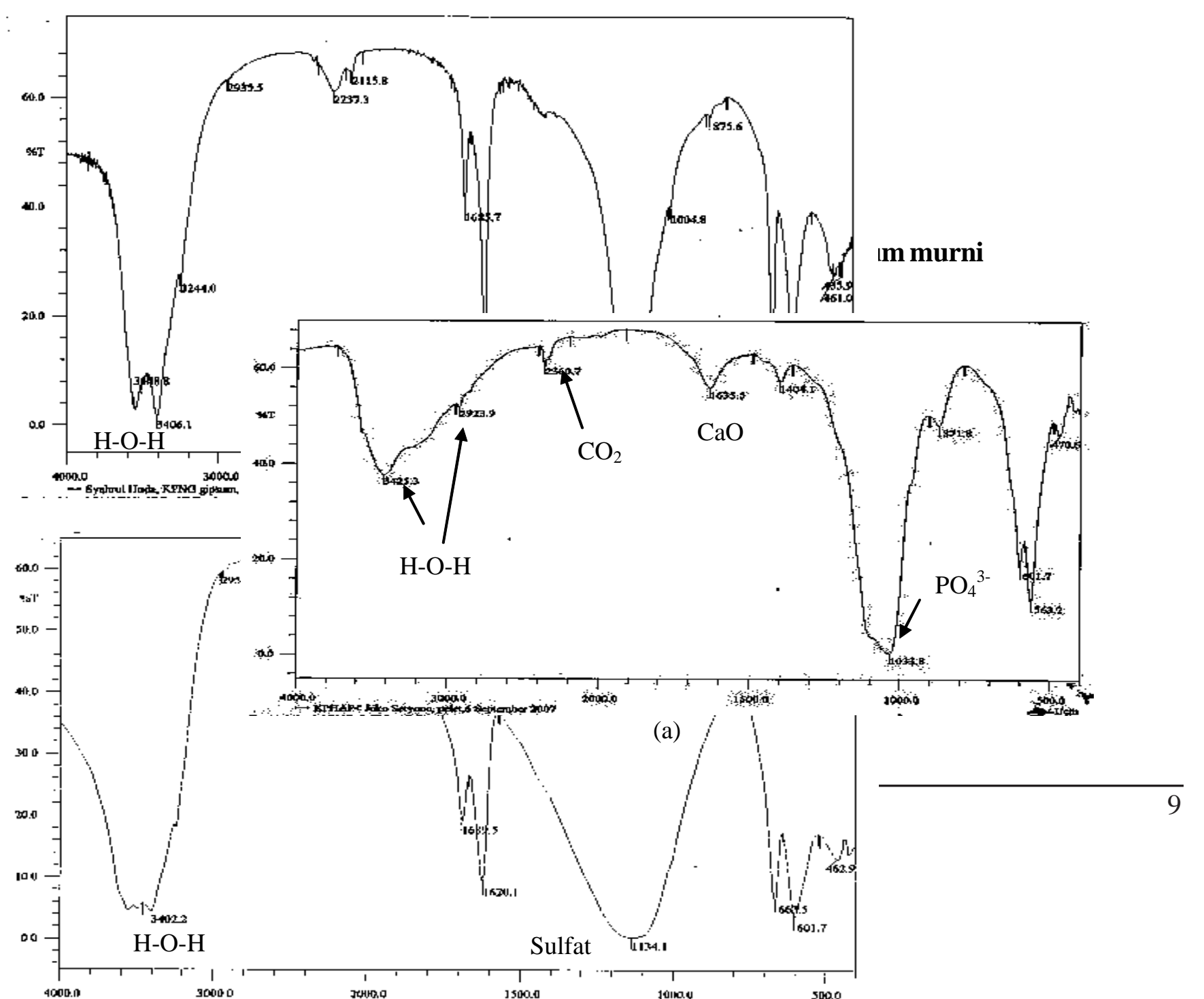




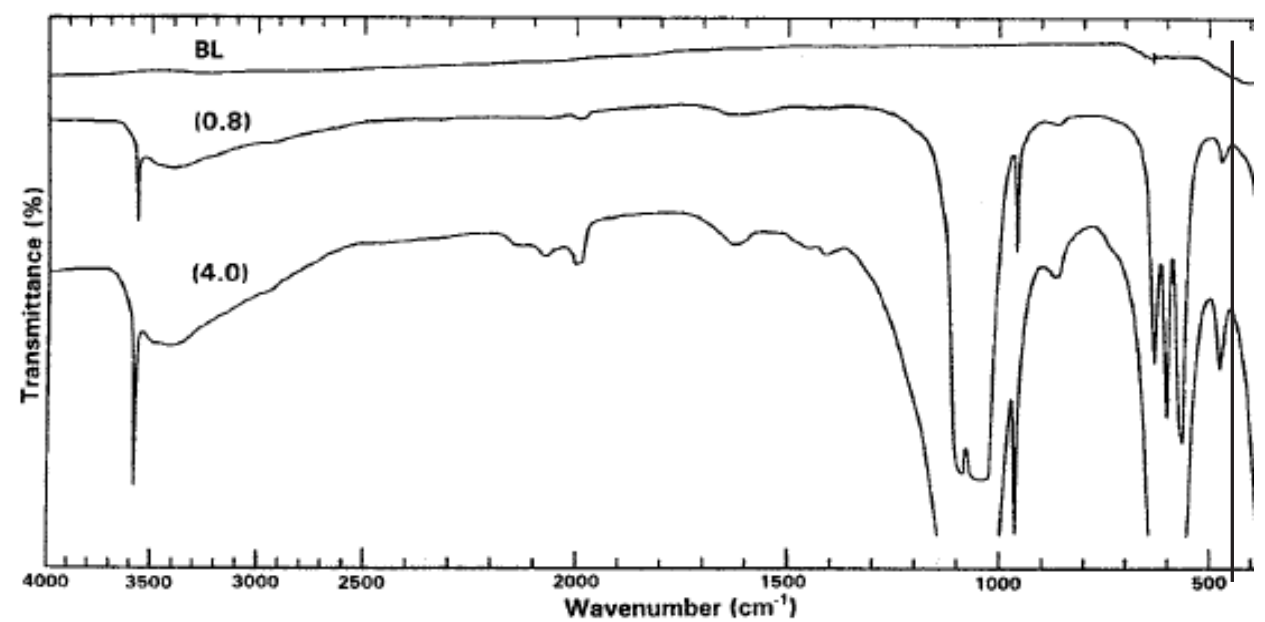

(b)

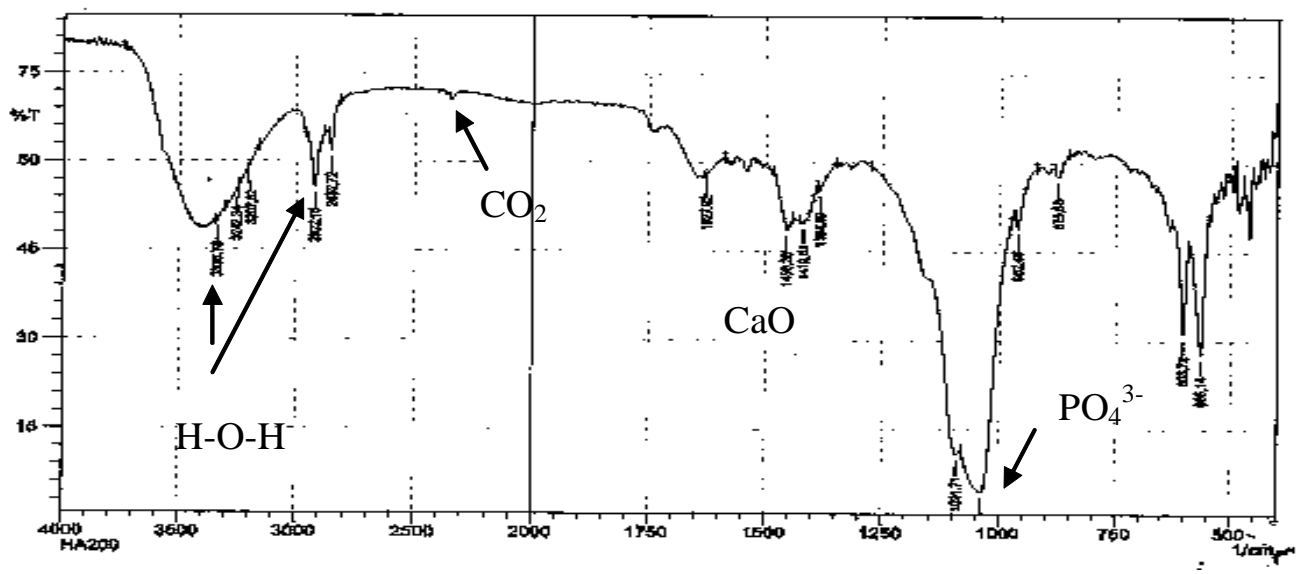

(c)

Gambar 3. Pola FTIR (a) KPHAp, (b) HAp SRM 2910, dan (c) HAp 200

Dari sini diyakini bahwa material yang digunakan sebagai bahan baku adalah benarbenar gipsum, dengan kemungkinan tingkat kemurnian $\mathrm{CaSO}_{4} \cdot 2 \mathrm{H}_{2} \mathrm{O}$ (kalsium sulfat dihidrat) pada KPNG yang tinggi yang sangat mendekati gipsum murni komersial.

Gambar 3 menunjukkan memperlihatkan pola FTIR (a) KPHAp, (b) HAp SRM 2910, dan (c) HAp 200. Dari gambar ini nampak adanya kemiripan pola FTIR KPHAp dengan HAp 2910 dan HAp 200. Spektra inframerah dari KPHAp menunjukkan adanya ikatan molekul hidrogen pada bilangan gelombang 3425,3 $\mathrm{cm}^{-1}$ dan 2923,9 $\mathrm{cm}^{-1}$. Spektra inframerah yang menunjukkan adanya ikatan molekul hidrogen terjadi pada bilangan gelombang $3412,08 \mathrm{~cm}^{-1}$ dan $3145,90 \mathrm{~cm}^{-1}$ yang ditandai dengan adanya vibrasi gugus fungsi dari H-O-H (Pramatarove, 2005). Sedangkan menurut Pattanayak dkk. (2005) ikatan OH terdapat pada vibrasi gelombang 3400 dan 630 $\mathrm{cm}^{-1}$.

Ikatan gugus fosfat $\left(\mathrm{PO}_{4}^{3-}\right)$ merupakan intensitas yang paling tinggi nampak pada bilangan gelombang yakni 563,2 $\mathrm{cm}^{-1}$ dan 601,7 $\mathrm{cm}^{-1}$ dan 1033,8 $\mathrm{cm}^{-1}$. Menurut Sasikumar (2006) intensitas yang paling tinggi merupakan ikatan gugus fosfat $\left(\mathrm{PO}_{4}^{3-}\right)$ yang ditandai dengan vibrasi bending dan stretching dari $\mathrm{P}-\mathrm{O}$ yang terdapat pada bilangan gelombang $503,21 \mathrm{~cm}^{-}$ ${ }^{1}, 603,72 \mathrm{~cm}^{-1}$, dan $1026,13 \mathrm{~cm}^{-1}$. Sedangkan menurut Pattanayak dkk. (2005) ikatan gugus fosfat $\left(\mathrm{PO}_{4}^{3-}\right)$ paling kuat dengan vibrasi stretching terdapat pada bilangan interval 
gelombang $1000-1150 \mathrm{~cm}^{-1}$ dan medium pada bilangan gelombang $960 \mathrm{~cm}^{-1}$. Untuk vibrasi bending diamati pada $560-610 \mathrm{~cm}^{-1}$.

Gugus fungsi senyawa fase $\mathrm{Ca}-0$ ditemukan dalam struktur ini yang ditandai dengan vibrasi pada gelombang $1404,1 \mathrm{~cm}^{-1}$ $1635,5 \mathrm{~cm}^{-1}$. Gugus fungsi senyawa fase $\mathrm{Ca}-0$ ditemukan pada vibrasi gelombang $1400 \mathrm{~cm}^{-1}$ $1700 \mathrm{~cm}^{-1}$ (Pattanayak dkk., 2005).

Ikatan $\mathrm{CO}_{2}$ memiliki intensitas yang sangat rendah muncul pada bilangan gelombang 2360,7 $\mathrm{cm}^{-1}$. Bilangan gelombang $2300 \mathrm{~cm}^{-1}$ yang merupakan ikatan $\mathrm{CO}_{2}$ memiliki intensitas yang sangat rendah yang diindikasikan berasal dari udara luar (Fernandes dkk., 2000).

Terbentuknya fasa hidroksiapatit pada KPHAp yang menyerupai HAp 200 komersial kemungkinan disebabkan oleh tingginya tingkat kemurnian dari senyawa kalsium sulfat dihidrat pada KPNG dan diamonium hidrogen fosfat (DHP) Merck Jerman (95\%), sehingga ketika direaksikan dengan perlakuan hidrotermal dengan menggunakan microwave dapat menyebabkan lebih mudah dan semakin cepat terbentuk ikatan antara unsur kalsium dan fosfat menjadi hidroksiapatit dan energi pembentukan yang sangat efisien (Khrisna dkk., 2002).

\section{KESIMPULAN}

Dengan menggunakan kalsium sulfat dihidrat Kulon Progo Jogjakarta yang direaksikan dengan diamonium hidrogen fosfat dengan metode hidrotermal dapat dihasilkan biokeramik hidroksiapatit $\left[\mathrm{Ca}_{10}\left(\mathrm{PO}_{4}\right)_{6}(\mathrm{OH})_{2}\right]$ yang mirip dengan produk hidroksiapatit impor. Hal ini ditandai dengan hasil karakterisasi FTIR. Ini semakin memperkuat kenyataan sebagaimana hasil karakterisasi XRD yang telah dipublikasikan sebelumnya (Sedyono dkk., 2007). Dan hal ini merupakan peluang bagi kita untuk mengembangkan sendiri hidroksiapatit di dalam negeri.

\section{PERSANTUNAN}

Ucapan terima kasih ditujukan kepada pemerintah dalam hal ini melalui Dirjen Dikti dalam program TPSDP dan Universitas Muhammadiyah Surakarta atas dukungannya dalam pelaksanaan penelitian ini.

\section{DAFTAR PUSTAKA}

Fernandes, F., Mauro, C. dan Laranjeira, M., 2000, Calcium Phosphate Biomaterials from Marine Algae Hydrothermal Synthesis and Characterisation, Quimica Nova, pp 441-446.

Furuta, S., Katsuki,H., Komarneni,S., 1998, Porous Hydroxyapatite Monoliths from Gypsum Waste, j mater chem 8: 2803-6

Katsuki, H., Furuta,S., Komarneni,S., 1999, Microwave Versus Conventional-Hydrothermal Synthesis of Hydroxyapatite Crystals from Gypsum, j am ceram soc 87 (8):2257-9

Krishna, D.S.R., Chatanya, C.K., Seshadri, S.K., dan Kumar, T.S.S., 2002, Flourinated Hydroxyapatite by Hydrolysis Under Microwave Irradiation, Trends Biomater. Artif. Organs. Vol. 16(1), pp 15-17

Nasution, D.A., 2006, Fabrikasi serta Studi Sifat Mekanis dan Fisis Biokeramik Hidroksiapatit (HAp) dari Kalsit Gunung Kidul, Tesis S-2, Sekolah Pasca Sarjana UGM, Jogjakarta.

Pattanayak, D.K., Divya, P., Upadhyay, S., Prasad, R.C., Rao, B.T. dan Mohan, T.R.R., 2005, Synthesis and Evaluation of Hydroxyapatite Ceramics, Trends Biomater. Artif. Organs, Vol 18 (2), January 2005. 
Pramatarove, L., 2005, Hydroxyapatite Growth Induced by Native Extracelluler Matrix Deposition on Solid Surface, European Cells and Materials, Vol. 9, pp 9-12.

Sasikumar, S., 2006, Low Temperature Synthesis of Nanocrystaline Hydroxyapatite from Egg Shells by Combustio Method, Trends Biomater. Artif. Organs, Vol. 19(2), pp 70-71.

Sedyono, J., Tontowi, A.E. dan Ana, I.D., 2007, Fabrikasi dan karakterisasi XRD Hidroksiapatit dari Gipsum Alam Kulon Progo, Prociding Seminar Nasional Perkembangan Riset dan Teknologi di Bidang Industri ke-13 UGM Jogjakarta. 